\title{
Generational "we-sense", "they-sense" and narrative: An epistemological approach to media and social change
}

Perspectiva generacional «we-sense», "they-sense» y narrativa: Una perspectiva epistemológica sobre medios y generaciones

\author{
Göran Bolin \\ University, Sweden \\ goran.bolin@sh.se (SUECIA)
}

Recibido: 13.022018

Aceptado: 30.09 .2018

\begin{abstract}
A classic epistemological problem in the social sciences is how to analyse and understand social change. In media and communication studies, for example, the concept of mediatisation has sparked off such a debate, since one of the main criticisms against the approach is that researchers rather take change for granted without being able to empirically establish if and how change has occurred. In this article is suggested a model for analysing social change through an analysis of how generational identity as "we-sense" is produced in narratives about media use. The empirical basis for the discussion is picked from a recently finished project on media generations in Sweden and Estonia, building on foremost qualitative material. The article concludes with accounting for the merits of using a generational perspective for analysing social change.
\end{abstract}

\section{KEY WORDS}

Generation identity, social change epistemology, cross-cultural analysis, social conscience of historical development. 


\section{RESUMEN}

Cómo analizar y comprender el cambio social es un problema epistemológico clásico en ciencias sociales. Sin embargo, en los estudios de comunicación, por ejemplo, el concepto de mediatización ha precipitado el debate, de manera que una de las principales críticas que se dirigen a los estudios realizados desde este concepto tienden a dar por sentado el cambio, sin llegar a establecer empíricamente si tal cambio ha ocurrido o cómo se ha producido. En este artículo, se sugiere un modelo para analizar el cambio social a través de un análisis de cómo la identidad generacional -entendida como "sentido compartido" (we-sense)- se produce en las narrativas sobre el uso de los medios de comunicación. La base empírica para la discusión deriva de un proyecto recientemente finalizado sobre las generaciones de medios de comunicación en Suecia y Estonia, fundamentado principalmente en material cualitativo. En artículo concluye resaltando el valor que tiene el uso de una perspectiva generacional para analizar el cambio social.

\section{PALABRAS CLAVE}

Identidad generacional, epistemología del cambio social, análisis transcultural, conciencia social del desarrollo histórico.

\section{INTRODUCCIÓN}

A classic epistemological problem in the social sciences is how to analyse and understand social change. In media and communication studies, for example, the concept of mediatisation has sparked off such a debate, since one of the main criticisms against the approach is that researchers rather take change for granted without being able to empirically establish if and how change has occurred (e.g. Deacon \& Stanyer 2015). To study social change means effectively 'taking time seriously' (Stanyer \& Mihelj 2016), and the wider purpose of this article is to contribute with an epistemological approach to such a debate. More specifically, the aim of this article is to discuss and suggest a model for analysing social change through an analysis of how a generational identity as "we-sense" is produced in narratives about media use, or perhaps, how media use and generational belonging over the life course is narrativised.

In order to fulfil this aim, I will exemplify my discussion with material from a recently finished project on media, generations and mediatised social change in Sweden and Estonia (Bolin 2016). The material is both quantitative and qualitative, being comprised of survey data on media use from Sweden and Estonia, collected every second year between 2002 and 2012 (national representative data from Estonia and both national representative data plus regional data from the south Stockholm region in Sweden), and of qualitative focus group interviews. In this article I will put an emphasis on the qualitative material based in eight 
focus group interviews conducted in late 2011 and early 2012, four in each country, with between four and eight participants in each group. These groups were constructed partly on the basis of historical development in the two countries, but also on the basis of the quantitative material, where breaking points in media use was identified, and related to their formative years (i.e. around the late teens and early twenties). ${ }^{1}$ For this article, I have not distinguished between Swedish and Estonian quotes, as I am not aiming at a cross-cultural analysis (for those interested, see Bolin 2016a and 2016b), and instead focussed on the intergenerational relations.

I will start discussing the epistemological implications of analysing time and social change in relation to generation - both generation as kinship and as social formation. I will then, in the subsequent section, discuss these temporal aspects in relation to space and suggest a model for how the media landscape can be accounted for, and why the landscape metaphor is more fitting than competing concepts for this type of analysis. In the section following that, I will discuss how one can locate different generations in this landscape, and then how one can analyse social change as a result of the ways in which generational narratives are produced. In a last section I will summarise my arguments for why a generational analysis is beneficial for the understanding of social change.

\section{GENERATION AS KINSHIP AND SOCIAL FORMATION}

One way in which to study temporal processes and especially social change is to study generational exchanges, the exchanges between 'contemporaries, predecessors and successors' as Paul Ricoeur (1985/1990: 113) has described it. Ricoeur, however, just as his scholarly predecessor Karl Mannheim (1928/1952), theorised time through generational successions, since he, following Wilhelm Dilthey (1875/1924), regarded generations as the intermediary between "the "external" time of the calendar and the "internal" time of our mental lives' (Ricoeur 1985/1990: 111). Social change can thus be studied via an analysis of generational exchanges, as they are understood from the meeting between a social formation and a geosocial space. In the rest of this section I will expand on the theory of generations, and how generations are formed. I will lead my way into this theoretical discussion by taking my point of departure in a family photograph.

Before the digital age, when taking a photograph was a less mundane activity, people used to arrange photos in albums. A typical photo that can be found in most family photo albums is the three-generation photo, taken at some festive family occasion such as the excursion to the beach on vacation, the celebration of someone's birthday, or the Christmas party, the graduation party, or at similar events. We typically find a group of people lined up before the camera, often spontaneously caught in the moment, or sometimes more professionally arran-

${ }^{1}$ For and account of the survey methodology, see Bolin \& Notini (2005), and for a detailed account of the selection criteria for the interviews, see Opermann (2014). 
ged, for example for weddings and other major life events (Bourdieu \& Bourdieu 1965/2004). Figure 1 displays such a picture from my own family album, taken during the summer of 1939 when my mother - the six years old girl in the white cap - made a visit to the birthplace of her parents during the summer vacation, visiting the relatives that were still living in this remote village in the north of Sweden. Her father - my grandfather - stands to the right of my mother, while her mother - my grandmother - can be seen in the background to the left, just behind her mother - my great grandmother. We can see from the composition of the photo that it is taken by an amateur: the woman to the right is partly outside of the frame (while we see large parts of a gravel road and woods to the left), and, because the photographer does not want to have the camera facing the sun, it results in all persons in the picture gazing towards the sun.

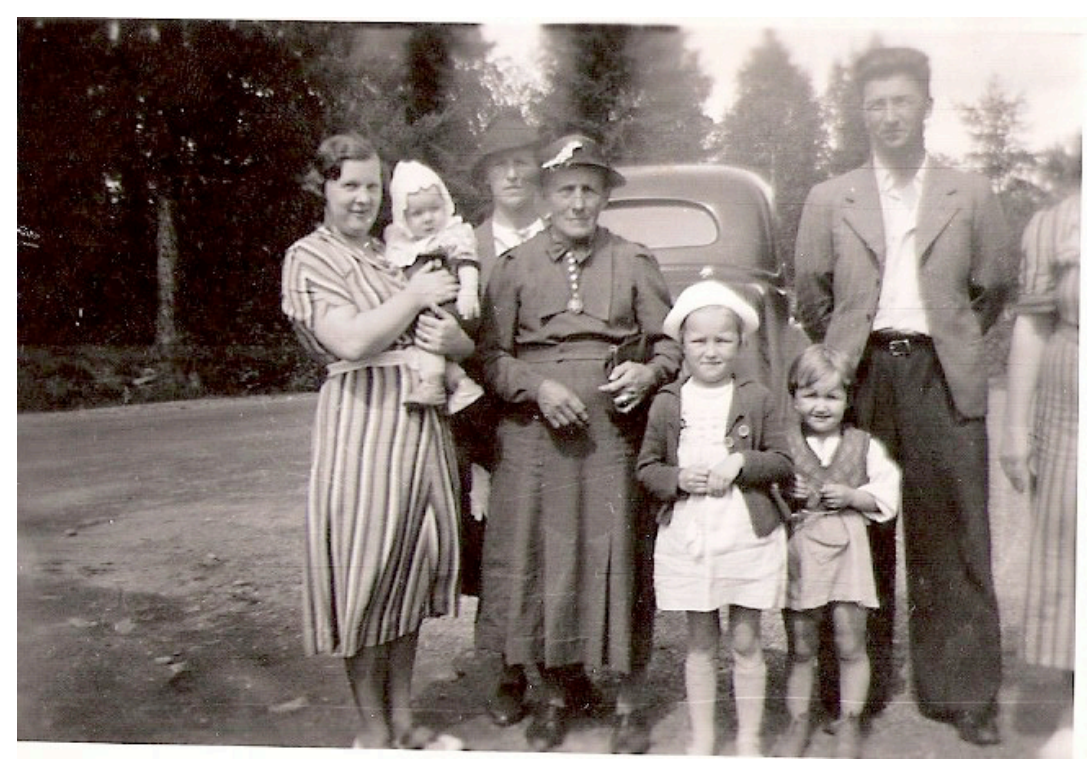

Figure 1: Family album - typical three-generation photo. Unknown photographer.

This is in many ways, then, a typical photo - practically a genre of its own (Kuhn 1995). To most people who sees it, its main meaning is the three-generation theme. It might also provoke some general questions of time: At the very moment when this photo was taken, World War II had not yet started; Sweden was still very much an agrarian country; the famous People's Home ideal and the welfare state was not yet realised, and so on. To me, however, it also means something else. It evokes the specific narrative of $m y$ family, the history of the young people who left the agrarian north to find work $650 \mathrm{~km}$ south in Stockholm, and who then stayed there for the rest of their lives. My mother was then born in Stockholm, just like I am, and she never lived anywhere else. 
When we look at generation photos in family albums, they are mainly emphasizing generational belonging as kinship. What we see is representations of different generations in the same family formation: for example, mother, daughter and grandmother. The 'we' in these pictures are 'we, the family'. This type of diachronic understanding of generations can be found most explicitly in theories of generation gaps, for example in Margaret Mead's (1970) scholarship, emphasizing the different types of learning that separates generations. Mead's preoccupation was with the rapid societal changes which would produce generation gaps, that is, how diachronic generations are separated by experience, rather than being integrated. The founding idea for this was the rapid societal transformations, described as 'the tremendous changes going on in the world in the period immediately following World War II' (Mead 1970: xi). Such rapid changes have also been of concern for other researchers who have theorized generational change:

Prior to the late nineteenth century media explosion, generations came and went, all exposed to and acquiring the same print grammar. Thus media seemed to have little bearing on human time relationships. Though we still think of people as related, or separated in chronological generation time, the rapid advent of new media and the acquisition of new media grammars implies new alignments, shorter and more diverse than those based on generations.

(Gumpert and Cathcart, 1985: 31)

If Mead was interested in the relations between diachronic generations due to rapid societal changes, Karl Mannheim (1928/1952) also wanted to understand change, but rather emphasized generation as a social formation, made up by coevals, that is, people of the same age, living at the same time, sharing the same or, at least, similar experiences. Such common experiences would then, presumably, connect people in a generational consciousness. The 'we-sense' felt by a generation as a social formation would then be the 'we' as in 'we, coevals' (cf. Corsten 1999). This intra-generational commonality could be contrasted with the emphasis that Mead made of the inter-generational differences between generations, and what could possibly be called the 'they-sense', that is, the sense of difference from older (and perhaps also younger) generations among coevals when 'young people everywhere share a kind of experience that none of the elders ever have had or will have' (Mead, 1970, p. 64).

Now, a 'we-sense' does not just appear - it has to be worked upon in the process that Andra Siibak and Nicoletta Vittadini (2012) call 'generationing', and which leads up to the generational formation. This process, they explain, is 'the result of the interaction between contextual and fixed traits (such as historical, cultural and social events and experiences) and a cultural process of identity formation developed over time (including narratives, performances and rituals)' (Siibak and Vittadini 2012: 3; cf. Alanen 2001).

According to this perspective of generationing, people are not born into a generation, but mould and form their generational identity over time. This is 
also the reason why it is easier to detect clear-cut generational formations among older generations who have lived longer than those whose identity is only emerging (Bolin 2016: 124ff). So, the fact that the baby-boomers, born in the 1940s, is the by far most analysed generational formation (see, e.g. Jamison \& Eyerman 1994, Bristow 2015), is simply due to the fact that they have rehearsed their generational identity over longer time than, say, the millennials. This rehearsal, however, does not occur in a vacuum. It occurs in relation to a specific historical context; In the words of Mannheim (1928/1952), it occurs in a specific location, under specific social, political, economic conditions. Some of these conditions concern the media, and we can thus think of this location as the media landscape as a specific space in which the generational succession takes place

\section{MEDIA LANDSCAPES ${ }^{2}$}

A media landscape is a mediatized space in which people live and act. It is a space in which we orient, and just as geographical landscapes, it impacts on our actions within it, sets limits, or privileges certain movements. Take, for example, an urban landscape with houses roads, sidewalks, etc. We have to adjust our actions in relation to these things. Pavements suggests paths for us to walk, streets are for driving or cycling, we cannot walk through houses or walls, and the paths in the park marks out the privileged route we are to move. Just like geographical landscapes, media landscapes are formed by individual or collective subjects, acting on the surrounding physical environment. But also our actions in a landscape impact on it. People may, for example, not always follow the paths through a garden, but make short-cuts over the lawn, producing a path not privileged by the gardener. Eventually such actions impact on the landscape itself.

An advantage of the metaphor of landscape that makes it more fitting for an analysis of generations than biological metaphors such as media environment or media ecology, which have the disadvantage that they point to the organic development of the media. But there is not any organic over the construction of the media around us. Media, both as technologies, organisations and sign structures, are produced by humans. They are not like plants that suddenly appear and spread, nor like rhizomic root systems. The metaphor of landscape, in short, allows for thinking about the media in a way that transgresses the structure-agency dichotomy and makes it possible to see action as structured by frameworks produced in previous social action, by preceding others. Those structures, however, are not determining, only privileging.

If we adopt this metaphor to the media and think of media landscapes, these involve three kinds of formative structures into which individual and collective subjects are born: those of technological relations, those of organisational relations and those of representations.

2 This section builds on sections in chapter three in Bolin (2016). 
Firstly, media technologies make up a terrain, an electronic geography in which people orient in their everyday lives. These technological landscapes make up an infrastructure of 'the material sites and objects involved in local, national and /or global distribution of audiovisual signals and data [that] include phenomena such as broadcast transmitters, transoceanic cables, satellite earth stations, mobile telephone towers, and internet data centers' (Parks 2015: 356). This material base is distributed in space in the form of technological systems, sometimes visible for us in the form of telephone wires in the sky, which changed the character of the urban landscape dramatically around the end of the 1800s (Garnert 2005: 87ff), or satellite dishes towards the end of the 1900s (Parks 2012). Sometimes, however, these systems are less visible. We can indeed observe television aerials or satellite dishes on the roofs of houses, but observing the actual waves in the air is harder. The same goes for the wi-fi networks that surrounds us in many public areas. We can see a list of them when we open the settings of our laptop or mobile, but the actual routers themselves can be harder to find, even if we might look for them. So, although it is not always visible to us, the technological landscapes have a material dimension that makes them differ from the symbolic landscapes: their consequences are more determining in that technology and the organisation of technology only allows for the actions it is designed for: early radio and television did not allow for listening to or watching programmes at a time chosen by the user, since it didn't have a storage and playback function. One had to obey to the time that was allotted by the broadcaster. The radio and television sets also did not allow for mobility, but were fixed entities that were having an impact on the ways in which we structured our domestic environments, our homes (cf. Spigel 1992).

Secondly, there are the organisational dimension of the media landscape, marked by the ways in which the media are organised, both separately as individual organisations, but also in combination. Individual media organisation can, for example be profit-driven, like commercial media companies, or public service, like some broadcasting organisations or they can be part of a larger, non-media organisation, and serving that larger firm. Whether a company is organised as a commercial enterprise or a public service one, will, of course, have an impact on the ways in which it addresses its audiences or users, for example as citizens or as consumers. Equally, the combination of the media into a total media landscape, will also have an impact on how media users can relate to this landscape. A landscape marked by strong public service companies will naturally be different from one that is totally dominated by commercially driven media companies.

Thirdly, there are the media landscapes that result from representational practices. Through the production of accounts, images and representations a semiotic web is constructed, a map in which we can act as individuals, but which also sets up limits, privileges certain kinds of actions before others, and guides us in our everyday lives. Each account of the world, each such map, pursues its own argumentation vis-à-vis the surrounding world, and these accounts will have impacts on it. Each of these maps are also firmly anchored in its own historical 
setting, and in retrospect we can only act towards them historically: When the author August Strindberg writes a description of telephone lines along the rooftops in Stockholm (that is, a technological structure), he is engaged in a representational practice, producing a map over a technological structure. However, the referent to this represented reality is not accessible for us today as terrain, only as map (cf. Garnert 2005: 112 and 145ff).

Through the media and their representations, we learn of places we have never been, some of which we will never visit (for example, since they concern past historical situations which we can only revisit as maps, not as terrain). These media texts make up landscapes saturated with ideas, values, apprehensions. All these kinds of mediated landscapes are laden with ideology, just as landscape paintings are ideological:

Landscape [...] is an instrument of cultural power, perhaps even an agent of power that is (or frequently represents itself as) independent of human intentions. Landscape as a cultural medium thus has a double role with respect to something like ideology: it naturalizes a cultural and social construction, representing an artificial world as if it were simply given and inevitable, and it also makes that representation operational by interpellating its beholder in some more or less determinate relation to its givenness as sight and site.

(Mitchell 1994/2002: 1f)

One can of course argue if the distinction that Mitchell does between the implicitly real and the 'artificial' is valid. I would rather argue that the symbolic landscapes are no less real than material, geographical landscapes. Symbolic landscapes are indeed ideological, both as constructs and as constructors of social reality: the ways in which things are represented will inevitably have consequences not only for how society is perceived in the present, but also for how it will be in the future. Representations are, then, both descriptive and prescriptive.

The symbolic landscape of the media, as both technology and representation, primarily talks to our visual and aural senses. As such, the impact on our actions is not as direct and determining, but it is not always as obvious either. The capacity of the media to naturalise what they represent makes the landscapes they produce much harder to identify and therefore also to resist. We are not always aware of the impact of the symbolic landscape in the same obvious way as we are of more manifest, physical ones. Physical landscapes are structured with roads, cities, bridges and canals, which privilege certain types of movement and action before others. In a similar way, the symbolic landscapes of technology and content also structure action, by making some kinds of actions more probable than others. The architecture of urban landscaping, for example, has its correspondence in the landscaping of the symbolic surroundings, in the architecture of the media.

But how can we, against the backdrop of this spatial understanding of the media, envision the relation between the structure of the media and social action within this structure? In the next section will be suggested a way to understand 
the dynamics of such a relation, and how this model can help understand social change.

\section{MEDIA LANDSCAPES AND TIME}

The succession of generations produces time, and the specific quality of this time is dependent on the character of the media landscape in conjunction with the more general social, political and cultural landscape. In Figure 2 below, we can see how potential generations, born in the early 1940s, early 1960s, late 1970s and early 1990s, can be tentatively located in a media landscape - in this case the media landscape of Sweden and Estonia. We can see the approximate arrival of each media technology, indicated on the timeline. There are very few dramatic differences in arrival of the technologies in Sweden and Estonia - but a construction of a media landscape in another geographical location can, of course, prove to differ in this respect.

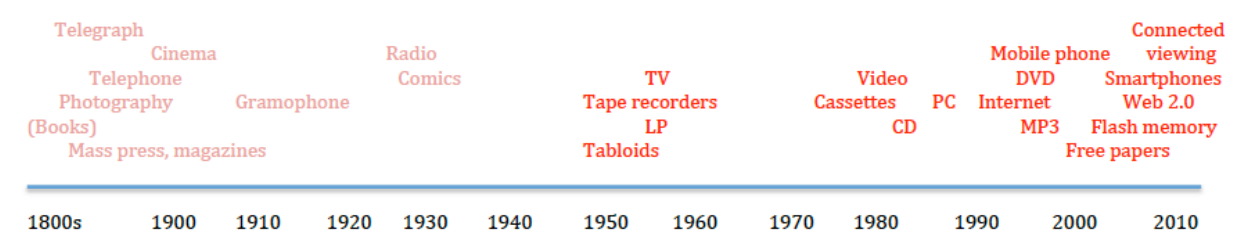

Potential generations

Figure 2: Four tentative generations located in the Swedish media landscape 1800s to present. Figure constructed by author.

In Figure 2 has been marked out the approximate time of arrival for the most common media technologies. The only mass medium that was already present at the turn of the Century 1900 - the book - is bracketed, and we can then see how continuously new technologies appear, and add to those already present. Accordingly, the media landscape gets denser over time, to the point where social life as such is embedded in media, making life a veritable media life (Deuze 2012). As individuals travel through the media landscapes, they also accumulate experience of it, adding to their experience of other societal events that occur. When individuals, or indeed social formations, move through the media landscape, this movement produces time in the same sense as Henri Lefebvre (1974/1991) has theorised time as movement in space. When individuals travel through the technological and symbolic landscape of the media, their movements on the one hand produces linear time (as in the timeline in figure 2), but also punctual time, that is, the time that is defined by its quality rather than where it can be located on a time axis. In this meaning, time receives its specific quality from the life 
histories, and the encounters between an individual, or a generation as a social formation, and a media landscape.

Figure 2 also indicate the four tentative generations that was constructed for the focus group interviews. They were chosen because they had their formative years at a time when either a new media technology was introduced and/or in relation to some major socio-political event. Those born in the early 1940 grew up in the immediate shadow of the Second World War, and saw the arrival of television in their late teens. Those born in the early 1960s were born and grew up during the Cold War, lived through some major media events during their upbringing, and were in their formative years at the time of the arrival of video and CD records. Those born in the late 1970s grew up during Soviet times and had their formative years shortly after the demise of the Soviet Union. They also were in their formative years at the time of the arrival of the personal computer. Lastly, those born in the early 1990s were born after independence (in Estonia), and in the post-Public Service era with strong commercial television and radio, and saw the a coming of mobile phones, personal computers and the Internet. Each of these tentative generations were supposed to be able to account for these things and relate those to their life histories.

Every life story contains a relation to contemporary media - be it radio, mass reproduced lithographs, mobile phones, etc. These relations can be studied through documents, as in Figure 3 below, or through life history interviews.

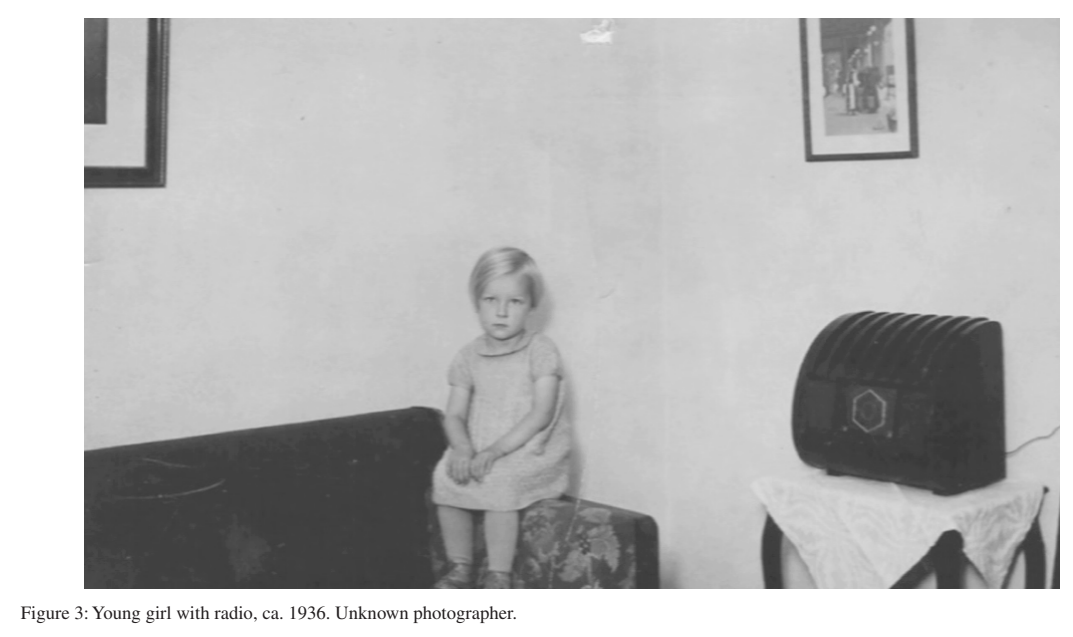

In Figure 3 we again find my mother, this time around the age of three, sitting in the one-room apartment where she then lived, beside the radio, and with two lithographs on the wall. Compared to three-year-old children of today, the media landscape of my mother (and her coevals) might seem ascetic. Of course she had access to books, newspapers and magazines, but there were no screen media available. At the time, radio was the new medium, but it was a medium 
that my mother was born into - it had always been there for her. For her parents, however, born as they were in the early 1900s, radio had been a novelty when it arrived in the mid-1920s. And so, every child is born into a prefigured structure that is the media landscape, that in combination with the general social and historical landscape is the location in which it is brought up. Over each person's lifetime, however, we can be certain that there will appear new media, and that these media will have an impact on the life of the generation and help mould it into a specific generation, with its own experiences and sentiments. Each new media encounter will have impact, but with Mannheim we can see that the impact on experience is stronger during the formative years of youth, that is, roughly between the ages of 17 and 25 .

However, even if encounters with media novelties might be important during the formative years, the generational identity does not become fixed, but is rehearsed over and over again during the life-course. This does of course not mean that an individual's generational identity is forefronted and acted out all the time; it rather becomes activated in certain moments such as a reunion with old friends or family members - or when a person is prompted during an interview. In a previous project on media and generations, focus group interviews were initialised with the prompting question 'Which media did you have in your home as a child? Can you tell us about your earliest media memories?'. On such occasions the generational identity becomes activated, and such a prompting question is often answered with a narrative built on memories of past media experiences be they from technologies or from media texts.

\section{GENERATION AND NARRATIVE}

In an interview situation, if you are asked to tell a story of your media memories, most people would, if only to please the interviewer, respond with a more or less elaborated narrative. These narratives might not always follow the dynamic of classical narratives as they are defined by, for example, literary analysts such as Tzetan Todorov (1969), where a story unfolds from a state of equilibrium, over the introduction of a problem which is then solved and equilibrium is restored. Indeed, the narratives of informants rarely reach narrative closure in that sense, and are more commonly in the form of fragments, for example describing a situation or a memory. Often these accounts are focussing social relations, for example between family members, and very often they concern generational relations such as those between fathers and sons, mothers and daughters, or other family relatives.

This is, for example, how an informant in a focus group interview conducted in 2012 accounted for his relation to his son, and to old mix-tapes on cassette tapes. 
Mats: Well, now, I had thrown most of them away, but I did save some. And then my son bought an old car with a cassette player in it. And he said "What's this?", and then we took one of my old tapes. And he almost fell over laughing, and then I had recorded... rapping... and a lot of such stuff. And he thought it was dead fun... plus a lot of old corny music, and he thought that was really great. He kept the tape. He sold the car eventually, and kept the tape. Thought that, "I'll keep this" (laughter).

Interviewer: And that was your son, right?

Mats: Yes, he bought an old car and there was a cassette player in it, and he, like, wanted to exchange it, and I said, no - keep it and I'll give you some tapes, and you can play them instead.

Interviewer: But was that because it was your cassette tape or was it because it was $a$ cassette tape?

Mats: A cassette tape. And then because I had added talk, and stuff. Mixed it together with songs and acted DJ in-between (laughter).

(Focus group, born 1962-1964)

Such shorter narratives that account for memories, events and relationships are in fact what most interviews are made up of. They are descriptions of past sentiments, sometimes nostalgic, sometimes fragmentary, but they most often take narrative form: they are many times coherent, often recounts of a situation, a relation between people, and in many cases have an end point. In the quote above, we can see that Mats in fact tells the same story twice, the second time repeated in somewhat more condensed form. However, for the most part, the stories are not that elaborated, but more very short accounts of an event that has stayed in the memory from childhood age:

I was four when I had diphtheria, and my aunt brought a picture book, a very nice book of Thumbelina to me in the Pilistvere hospital.

(Marie, born 1940)

The narrative here is much shorter, no doubt because Marie was only four years old at the time, and this is a fragment that she remembers - a description of an event that represents her being hospitalised with a severe illness at young age.

However, narratives are not only descriptive in their representations of various different generational memories. They are also prescriptive, in the sense that they are instructions and suggestions for how one could or should feel, what one should remember and how one should act as a member of a certain generation. These prescriptions can be found in special features in newspapers and magazines, in cinema films, novels or documentaries on television. And over the years these narratives are rehearsed over and over again, and produces a formula that becomes increasingly refined over the life-course. This formula contains both direct inter-generational references ('they-sense'), as well as indirect, intragenerational confirmation ('we-sense').

They-sense is most clearly visible in interview situations when informants refer directly to other generations - older or younger - by marking difference: 
Our generation seems to have quite a lot of similarities in their media use. When you look at people who are 10-15 years younger, they are many times more superficial. It's another world actually.

(Focus group, born 1976-1980)

This can be contrasted with the expressed we-sense, where the generational identity gets confirmed among interviewees:

Interviewer: I mean, what kind of films did they show mostly at that time? Aire: Indian films.

Marika: Yes, Indian films.

Ruth: French comedies.

Aire: Yes. Louis de Funes.

Tomas: Louis de Funes, yes.

Marika: Oktober or Pioneer, the one on Viru street where they showed one film all day and you could enter whenever you wanted.

Tomas: Yes, yes.

(Focus group, born 1959-1966)

In the interview excerpt we can see how the participants in the group interview confirm each other's memories with the phatic 'yes, yes'. The we-sense of generations means that the generation as a social formation recognises itself through common experiences, while 'they-sense' is produced when the members of the social formation acknowledges their commonality in opposition to "other" generations.

Yet another form of narrative is the meta-narrative, where the account concerns someone else telling the story. Consider this example where Ivan and Andres recollect the lack of children's programmes on television in Soviet Estonia in the wake of the death of Leonid Brezhnev, at the time when the boys were in the ages of five and six respectively:

Ivan: When Brezhnev died [1982], there was... mourning! And...

Andres: A day off school!

Ivan: I don't know... I didn't go to school yet, but... there were no kids' shows on TV for several days. My mum has told me that I and my sister had said that well... we'd had enough of mourning and we wanted kids' TV shows.

(Focus group, born 1976-1977)

This story has clearly been rehearsed as an anecdote within Ivan's family ('my mother has told me'), as well as within the journalistic and historical summaries of the late Soviet period in the 1980s. The story about changes in the television schedules are, for example, accounted for on BBC News's website under the heading 'On this day 1950-2005', where it is described how all entertainment programmes 'were replaced by sombre documentaries about the Russian revo- 
lution and the Second World War', and that newsreaders on the main news programme 'dressed in black but made no announcement of any death'. ${ }^{3}$ One could in fact say that the subjective narratives of family memories were blended with official journalistic historical accounts.

Now, these narratives reveal the perception of societal change, but it is the perception of common experiences that bind people together rather than events themselves. By emphasising one's own identity as a generation as social formation and distinguishing that generation towards other generations, one produces a narrative of change in which change is so rapid that people who are just ten or fifteen years younger live in 'another world actually', as the informant exclaims in the quote above. When difference is perceived in this way, this is more than just perception since 'if men define situations as real, they are real in their consequences' as the Thomas theorem goes (Thomas \& Thomas 1928: 572; cf. Merton 1995). But as people act in relation to their perceptions, actual change occur.

\section{CONCLUSION}

I have in the above tried to account for an epistemological approach to analysing social change via the study of how 'we-sense' and 'they-sense' is constructed in the generational succession order, and how these generational constructions are made in specific media landscapes. I have also tried to show how a combination of generational approaches can be fruitfully adopted: the diachronic approach of, for example, Margaret Mead (1970), who emphasised intergenerational relations and 'generation gaps', with the perspective on generations as social formations indicated by Mannheim (1928/1952). A generation gap is really the effect of a felt they-sense among generational formations, but it is also that they-sense that help produce social change, both in the form of perceptions among generations, and following from subsequent action, change indeed occurs. As already mentioned, it has at times been pointed out that media studies have not taken time and social change seriously enough (Stanyer \& Mihelj 2016), and when reading much generational analysis it is easy to agree with such a position - not least because much generational analysis focus on one single generational cohort (e.g. the 'baby boomers'). However, focussing on one single generation is not enough if one wants to understand how social change occurs. The combination of the synchronic generation as social formation in the sense of Mannheim, with a perspective on generation as succession, in Mead's analysis, where it is the intergenerational relations that are at focus, is one way to further our understanding of how social change occurs.

${ }^{3}$ http://news.bbc.co.uk/onthisday/hi/dates/stories/november/10/newsid 2516000/2516417. $\underline{\text { stm. }}$ Last accessed 13 July 2018. 


\section{REFERENCES}

Alanen, L. 2001. Childhood as Generational Condition: Children's Daily Lives in a Central Finland Town. In L. Alanen \& B. Mayall (eds) Conceptualizing Child-Adult Relations. London: Routledge, 129-143.

Bolin, G. 2016a. Media generations: Experience, identity and mediatised social change. London \& New York: Routledge.

Bolin, G. 2016b. The Rhythm of Ages: Analysing Mediatization through the Lens of Generations across Nations. International Journal of Communication. 10: 52525269.

Bolin, G. and Notini, A. 2005. Character of Sample and Responses. In G. Bolin (ed.): The Media Landscape of Södertörn 2002. Media Use, Values and Everyday Life in Southern Stockholm. Huddinge: MKV, 57-76.

Bourdieu, P. and Bourdieu, M-C. 1965/2004. The Peasant and Photography. Ethnography 5(4): 601-616.

Bristow, J. 2015. Baby boomers and generational conflict. Basingstoke, UK: Palgrave Macmillan.

Corsten, M. 1999. The time of generations. Time \& Society, 8(2): 249-272.

Deacon, D. and Stanyer, J. 2014. Mediatization: Key Concept or Conceptual Bandwagon? Media, Culture \& Society, 36(7): 1032-1044.

Deuze, M. 2012. Media Life. Cambridge: Polity.

Dilthey, W. 1875/1924 Über das Studium der Geschichte der Wissenschaften vom Menschen, der Gesellschaft und dem Staat. Wilhelm Diltheys Gesammelte Schriften, Bd. VI. Leipzig \& Berlin: Verlag von G.B. Teubner, pp. 36-41.

Garnert, J. 2005. Hallå! Om telefonens första tid i Sverige. Lund: Historiska Media.

Gumpert, G. and Cathcart, R. 1985. Media grammars, generations and media gaps'. Critical Studies in Mass Communication, 2(1): 23-35.

Jamison, A. and Eyerman, R. 1994. Seeds of the sixties. Berkeley, CA: University of California Press.

Kuhn, A. 1995. Family secrets. Acts of memory and imagination. London: Verso.

Lefebvre, H. 1974/1991. The production of space, Oxford \& Cambridge: Blackwell.

Mannheim, K. 1928/1952. The problem of generations. In: K. Mannheim Essays in the Sociology of Knowledge. London: Routledge \& Keegan Paul. pp. 276-320.

Mead, M. 1970. Culture and commitment: $a$ study of the generation gap. Natural History Press/Garden City, NY: Doubleday.

Merton, R.K. 1995. The Thomas Theorem and the Matthew Effect. Social Forces 7(2): $379-424$.

Opermann, S. 2014. Generational Use of News Media in Estonia: Media Access, Spatial Orientations and Discursive Characteristics of the News Media, Huddinge: Södertörn University.

Ortega y Gasset, J. 1923/1931. The modern theme. London: The C.W. Daniel company.

Parks, L. 2012. Technostruggles and the Satellite Dish: A Populist Approach to Infrastructure'. In G. Bolin (ed.): Cultural Technologies. The Shaping of Culture in Media and Society. New York: Routledge, 64-86.

Parks, L. 2015. 'Stuff You Can Kick': Toward a Theory of Media Infrastructures. In P. Svensson \& D. T. Goldberg (eds): Between Humanities and the Digital. Cambridge, MA: MIT Press, 355-373.

Pilcher, J. 1998. Women of their time: generation, gender issues and feminism. Aldershot: Ashgate. 
Ricoeur, P. 1985/1990. Time and narrative. Vol. 3. Chicago and London: The University of Chicago Press.

Rosa, H. 2005/2013. Social acceleration: a new theory of modernity. New York: Columbia University Press.

Siibak, A. and Vittadini, N. 2012. Introducing four empirical examples of the "generationing" process. Cyberpsychology, 6(2): 1-10. http://dx.doi.org/10.5817/CP201221.

Siibak, A. Vittadini, N and Nimrod, G. 2014. Generations as media audiences: an introduction. Participations, 11(2): 100-107.

Spigel, L. 1992. Make Room for TV. Television and the Family Ideal in Postwar America. Chicago \& London: University of Chicago Press.

Stanyer, J. and Mihelj, S. 2016. Taking Time Seriously. Theorizing and Researching Change in Communication and Media Studies. Journal of Communication, 66(2): 266-279.

Thomas, W.I. and Thomas, D.S. 1928. The Child in America: Behavior Problems and Programs. New York: A.A. Knopf.

Todorov, T. 1969. Structural Analysis of Narrative. Novel: A Forum of Fiction 3(1): 7076. 